\title{
OS RELATOS DE VIAGEM E A INVENÇÃO DA AMÉRICA BÁRBARA
}

\section{THE TRAVEL REPORTS AND THE INVENTION OF BARBARA AMERICA}

\author{
Fabiana Santos da Silva \\ UNILA \\ Mirian Santos Ribeiro de Oliveira \\ UNILA
}

Resumo: Este artigo examina os seguintes relatos de viagens, escritos por exploradores europeus, acerca de suas experiências na América: "Mundus Novus”, de Américo Vespúcio (1454-1512), publicado em 1505; "Duas viagens ao Brasil”, de Hans Staden (1525-1576), publicado em 1557; e, nesse mesmo ano, “As singularidades da França Antártica”, de André Thevet (1516-1590). Esse trabalho se ocupará em responder como essas publicações podem ter delimitado o olhar europeu sobre a América. O objetivo é demonstrar como essas narrativas desumanizaram os povos originários ao fazer referência ao canibalismo como uma conduta generalizada entre os ameríndios. O quadro teórico é formado pelos estudos de autores como Álvaro Manuel Machado e Daniel-Henri Pageaux; Edmund O’Gorman; e Fernando Cristóvão. Constata-se que as experiências narradas apelaram, sobretudo, para o tema da "barbárie indígena” e serviram, por séculos, como as únicas referências sobre o Novo Mundo. Devido à grande recepção que tiveram na Europa, os relatos de viagem podem ser vistos como agentes importantes no processo de invenção da América pelo Ocidente.

Palavras-chave: Literatura de viagem. América. Invenção. Barbárie.

Abstract: This article examines the following travel reports written by European explorers about their experiences in America: "Mundus Novus”, by Américo Vespúcio (1454-1512), published in 1505; “Duas viagens ao Brasil”, by Hans Staden (1525-1576), published in 1557; and, that same year, "As singularidades da França Antártica”, by André Thevet (1516-1590). This paper will focus on how these publications may have delineated the vision of Europeans about America. The purpose is to demonstrate how these narratives dehumanized the original peoples by referring to cannibalism as a generalized conduct among Amerindians. The theoretical reference of this research is formed by the studies of authors such as Álvaro Manuel Machado and Daniel-Henri Pageaux; Edmund O’Gorman; and Fernando Cristovão. It is concluded that the experiences narrated appealed, above all, to the theme of "indigenous barbarism" and served, for centuries, as the only references to the New World. The great reception of the the travel reports in Europe can be seen as an important agent in the process of America invention by the Occident.

Keywords: Travel Literature. America. Invention. Barbarism. 


\section{Introdução}

Considerando a grande circulação que tiveram na Europa quinhentista os relatos de viagem acerca do Novo Mundo - sem entrar na problemática desse termo -, esse trabalho pretende responder como essas publicações podem ter definido o olhar europeu sobre a América. Parte-se da hipótese de que essa literatura exerceu um papel considerável na invenção da ideia de barbárie indígena, pois, em meio a tantos outros elementos que poderiam ser observados, o canibalismo pautou boa parte dessas criações escritas e visuais.

Em termos metodológicos, o objeto de estudo desse trabalho é formado por relatos de viagens realizadas na América e que alcançaram grande sucesso editorial na Europa, já desde o século XVI. São eles: "Mundus Novus", de Américo Vespúcio (1454-1512), publicada em 1505; "Duas viagens ao Brasil”, de Hans Staden (1525-1576), publicada em 1557; e, nesse mesmo ano, "As singularidades da França Antártica”, de André Thevet (1516-1590). O objetivo desse trabalho é demonstrar como essas narrativas desumanizaram os povos originários ao fazer referência ao canibalismo como uma conduta generalizada entre os ameríndios, convencendo uma Europa, ávida por notícias do outro lado do Atlântico, da suposta ideia de barbárie indígena.

\section{Os relatos de viagem acerca do Novo Mundo}

A América aguçou profundamente a curiosidade da Europa, porquanto desde a viagem de Colombo, em 1492, vinha se revelando uma grande massa de terra firme, cuja existência, volume e independência geográfica em relação ao orbis terrarum pareciam totalmente improváveis, pelo menos, até aquele momento. Aos viajantes que retornavam, restava a incumbência de descrever o que viram nesse lugar, dando origem a uma América representada por meio de cartas e crônicas, hoje bastante estudadas no âmbito do que se convencionou chamar de literatura de viagem que, por sua vez, abarca as narrativas de viajantes acerca de suas experiências e percepções somadas durante um dado percurso.

Álvaro Manuel Machado e Daniel-Henri Pageaux (1988, p. 37) explicam que "(...) a literatura de viagem tem como barreiras cronológicas as grandes descobertas, na alvorada desses chamados 'tempos modernos', e os grandes empreendimentos coloniais da segunda metade do século XIX". De forma semelhante, Fernando Cristóvão (1999, p. 35) entende essa escrita como "o subgénero literário que se mantém vivo do século XV ao final do século XIX, cujos textos, de carácter compósito, entrecruzam Literatura com História e Antropologia, indo buscar a viagem real ou imaginária (por mar, terra e ar) temas, motivos e formas". Sobre o assunto, o autor tece ainda as seguintes considerações: 
E não só a viagem enquanto deslocação, percurso mais ou menos longo, também ao que, por ocasião da viagem pareceu digno de registro: a descrição da terra, fauna, flora, minerais, usos, costumes, crença e formas de organização dos povos, comércio, organização militar, ciências e artes, bem como os seus enquadramentos antropológicos, históricos e sociais, segundo uma mentalidade predominantemente renascentista, moderna e cristã (CRISTÓVÃO, 1999, p. 35).

É importante atentar para esse tipo de descrição a que Cristóvão (1999) se refere, especialmente se consideramos que, para o campo de investigação da literatura comparada, os primeiros relatos de viagem a respeito da América fornecem uma vasta possibilidade de análise, pois comportam o emprego da ficção nas primeiras narrativas de estranhamento do europeu em relação à América indígena.

A invenção da América - concepção sobre a qual logo refletiremos valeu-se de uma série de valores morais e filosóficos da cultura Ocidental, entre eles, o conceito de barbárie. Desde os gregos, o termo já era utilizado para se referir, de forma bastante pejorativa, aos estrangeiros como sinônimo de inferioridade ou ausência de civilização. O escritor Carlos Geovane Steigleder (2010, p. 64) explica que "o encontro de culturas completamente díspares, a europeia e a indígena, transformou-se num conflito entre 'civilizado’ e ‘barbárie’. Os europeus, evidentemente, eram os portadores da missão civilizatória que beneficiaria os índios, salvando-os da sua barbárie”. Nesse processo, foi de grande peso a profusão de relatos de viagens a respeito do Novo Mundo, cuja circulação é possível de ser identificada na Europa, já no início do século XVI.

A partir de relatos, como os de Américo Vespúcio, Hans Staden e André Thevet, os europeus constituíram uma ideia bastante negativa sobre a América, o que encontrará eco também em outros autores quinhentistas e seiscentistas. Vespúcio compara o indígena às "bestas", termo que provém do latim bestia, atrelado ao significado de "fera” ou "animal”. Essa associação, aliás, entre índio e animalidade, foi largamente explorada pelos defensores da colonização, que questionaram a própria natureza humana dessas populações. No âmbito religioso, o termo possui uma conotação ainda mais sombria, por fazer referência direta à figura do Anticristo, enviado pelo diabo para enganar as nações - "Vi sair do mar uma besta que tinha dez chifres e sete cabeças, e sobre os seus chifres dez diademas, e sobre as suas cabeças nomes de blasfêmia” (APOCALIPSE, 13: 11). Vale, pois, destacarmos as seguintes impressões deixadas por Vespúcio acerca da sua viagem ao continente, realizada entre 1501 e 1503:

O filho copula com a mãe; o irmão com a irmã; o primo com a prima; o transeunte e os que cruzam com ele. Quantas vezes querem, desfazem os casamentos, nos quais não observam nenhuma ordem. (...) As mulheres quando podiam juntar-se aos cristãos, impelidas pela forte libido, 
contaminavam e prostituíam toda pudicícia (...). Vi carne humana salgada suspensa nas vigas das casas, como é costume entre nós pendurar toucinho e carne suína. Digo mais: eles se admiram de não comermos nossos inimigos e de não usarmos a carne deles nos nossos alimentos, o que, dizem ser, saborosíssimas (VESPÚCIO, 2003, p. 42-44).

Se o trecho acima, embora curto, já era o bastante para se inventar uma imagem assustadoramente depreciativa a respeito das populações indígenas, quanto mais se considerarmos todo o conteúdo desse material, incluindo as imagens, que podem ser pensadas com um dos principais reforços para veiculação da ideia de barbárie indígena. É o caso da gravura "Imagem do Novo Mundo”, do gravurista suíço Johan Froschauer, que compôs a primeira edição ilustrada de Mundus Novus (Figura 1).

Figura 1: Imagem do Novo Mundo.

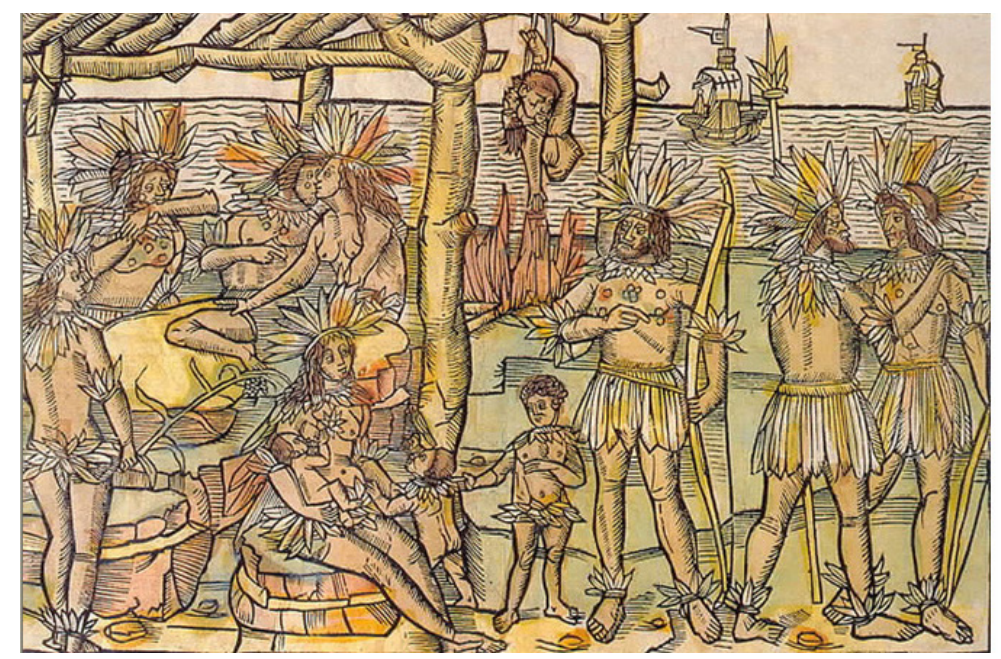

Fonte: CHICANGANA-BAYONA (2010, p. 37).

Essa ilustração chama a atenção pelo ar corriqueiro que o artista dá ao consumo de carne humana, ignorando todo o aspecto simbólico desse ato. A mãe amamenta cercada de corpos humanos, cortados e pendurados nas estruturas de uma cabana. Outros parecem conversar. A presença de mais duas crianças brincando reforçam a naturalidade do ato. Uma mulher divide sua atenção entre o companheiro e um tronco humano. Ao fundo, as caravelas convencem sob a condição de "barbárie" encontrada pelos espanhóis ao chegarem ao Novo Mundo. Destacamos que as primeiras edições - provavelmente entre 1503 e 1504 - das cartas atribuídas a Vespúcio ainda não continham imagens. A primeira edição ilustrada só ocorreu em 1505. Como explicar essa inserção? A esse respeito, Cristóvão (1999, p. 26) explica que "a fim de melhor agradarem aos leitores, as edições passaram a ser acompanhadas de muitas ilustrações, gravuras, desenhos e mapas”, pois 
os leitores se mostravam cada vez mais exigentes, demandando relatos cada vez mais minuciosos. A respeito desses leitores, o autor esclarece:

Não bastavam a descrição das rotas e itinerários nem as paisagens exóticas ou os tipos humanos, usos e costumes desconhecidos, nem eram suficientes as narrativas de ações aventurosas ou trágicas. Os leitores queriam mais, exigiam ver, queriam a representação desses itinerários, a reconstituição geográfica dos países, a traça dos monumentos, desejavam formar ideias exatas sobre os animais e as plantas que não conheciam. Assim as ilustrações eram cada vez mais abundantes e perfeitas, mesmo quando não eram exigidas pelos textos (CRISTÓVÃO, 1999, p. 32-33).

Para Machado e Pageux (1988, p. 58-59), toda e qualquer imagem é “representação de uma realidade cultural estrangeira através da qual o indivíduo ou o grupo que a elaboraram (ou que a partilham ou que a propagam) revelam e traduzem o espaço ideológico no qual se situam”. Além disso, a imagem é uma "linguagem sobre o Outro (...) que designa e significa”. Segundo Chicangana-Bayona (2010, p. 52), “as primeiras gravuras sobre antropofagia no Novo Mundo que ilustram as cartas de Vespúcio geraram uma imagem negativa dos seus habitantes” (...) além de conter “(...) elementos básicos que serão 'herdados' e estarão presentes na iconografia do canibalismo do índio durante o século XVI”, o que nos remete à obra “As singularidades da França Antártica”, de autoria do teólogo francês e frade franciscano André Thevet, publicada em Paris no ano de 1557. Trata-se de um relato de viagem acerca de sua estadia de dez semanas no Brasil, ocorrida entre 1555 e 1556, mais especificamente na França Antártica, colônia francesa correspondente à atual Baía de Guanabara. De forma semelhante a Vespúcio, ele relata:

A maior das vinganças praticadas pelos selvagens, a que me parece ser a mais cruel e indigna, é a de devorar os inimigos. Quando capturam prisioneiros de guerra e não têm condições de conduzi-los à sua aldeia, cortam-lhes os braços ou as pernas e, se houver tempo antes de recomeçar o combate, devoram-nos ali mesmo, enquanto não chega a hora de se retirarem do local. Caso contrário, cada um leva seu pedaço maior ou menor. Sempre que podem, levam os cativos para a sua aldeia, mas ali também o devorarão posteriormente (THEVET, 1978, p. 128 apud STEIGLEDER, 2010, p. 80).

A passagem, acima citada, está presente na obra “As singularidades da França Antártica” - publicada 55 anos após “Mundus Novus”. Ou seja, os relatos de viagem continuavam a chamar a atenção para a antropofagia praticada na América. Assim como Vespúcio, Thevet também colocou os indígenas no mesmo nível dos animais: “os americanos, além disto, são bem conformados e possuem membros bem proporcionados. Seus olhos, contudo, são mal feitos, ou seja, são negros e vesgos. Esta característica confere ao seu olhar um aspecto que lembra o das feras selvagens (THEVET, 1978, p. 102-103 apud STEIGLEDER, p. 60)”. Assim como fizera Vespúcio, 
Thevet faz uma referência direta à ideia de barbárie, associando-a não só ao canibalismo, como também à libidinosidade:

Os moradores, dantes tão cruéis e desumanos, aos poucos foram mudando seus procedimentos e adquirindo melhores costumes, deixando de ser bárbaros e cruéis para se tornarem presentemente humanos e corteses. Assim, não mais se pratica ali antigos atos de incivilidade, desumanidade e selvageria, como, por exemplo, os de se matarem uns aos outros, de comerem carne humana, de terem relações com a primeira mulher que encontrassem, não lhes importando laços de sangue ou parentesco (...) (THEVET, 1978, p. 236 apud STEIGLEDER, 2010, p. 68).

Na visão de Thevet, essa mudança de comportamento operada entre os indígenas se deu graças à presença dos franceses na Baía de Guanabara que, entre 1555 e 1570, foi ocupada com auxílio dos índios Tupinambás. Transparece-se a ideia de que, apesar do aparente estado de barbárie, as populações da América poderiam ser resgatadas da sua selvageria mediante a penosa missão civilizatória do homem branco. A salvação da América passaria, necessariamente, pela compaixão e missão civilizatória da Europa. Não é à toa que, para esse viajante, essas populações há muito estavam “(...) à espera do dia em que o contato com os cristãos lhes extirpe esta brutalidade, para que eles passem a vestir-se, adotando um procedimento mais civilizado e humano” (THEVET, 1978, p. 98 apud STEIGLEDER, 2010, p. 76).

É interessante observar que, assim como o relato de Vespúcio, o longo relato de Thevet também é acompanhado de ilustrações que reforçam suas observações acerca da sua experiência no Brasil. São 41 imagens - entre elas, do gravurista Jean Cousin - que endossam o que a escrita, sozinha, já conseguia fazer muito bem: reforçar a representação do indígena bárbaro. A Figura 2, que ilustrou sua obra, chama a atenção para o canibalismo entre os indígenas.

Figura 2: Desmembramento da vítima.

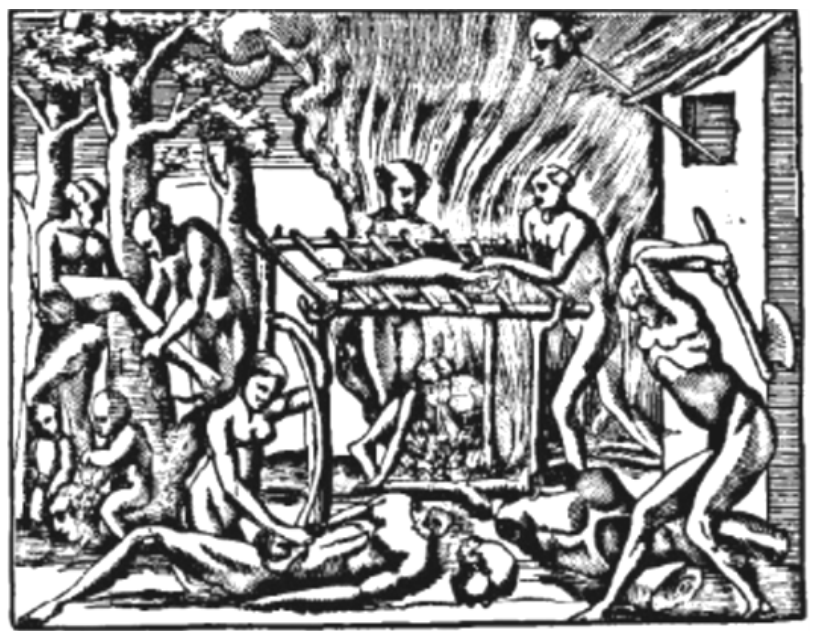

Fonte: THEVET (1878, p. 202). 
Nessa imagem, observa-se que os adultos se ocupam em desmembrar e assar os corpos, enquanto duas crianças se divertem com uma cabeça recém-decepada. A segunda cabeça está espetada no alto da cabana, como sinal de vitória. A terceira acaba de ser decapitada e receberá um novo golpe do índio armado com o machado. Uma indígena aparece prostrada retirando os miúdos do cadáver, lembrando relatos que, segundo Almeida (2002, p. 126), explicam que "o sangue, recolhido em cabaças, assim como os miúdos, era transformado em mingau e consumido pelas mulheres e pelas crianças”.

Nos relatos de viagem do artilheiro alemão Hans Staden (1525-1576), também encontramos impressões semelhantes: “(...) imediatamente as mulheres levam o morto (...). As vísceras são dadas às mulheres. Fervemnas e com o caldo fazem uma papa rala, que se chama mingau, que elas e as crianças sorvem” (STADEN, 1974, p. 182-184 apud FRANÇA, 2012, p. 246). Esse viajante esteve no Brasil em duas oportunidades: em 1549, passando por Pernambuco e pela Paraíba, e 1550, por Santa Catarina e São Vicente. Nesse último período, foi mantido preso pelos Tupinambás por cerca de nove meses, sob a constante ameaça de ter o seu corpo apreciado como iguaria alimentícia. Conseguiu voltar para a Europa. Seu relato, "Duas viagens ao Brasil”, foi publicado em Marburgo, Alemanha, em 1557, mesmo ano de publicação do relato de Thevet, citado anteriormente. Ainda no que se refere ao canibalismo, nos relatos de Staden encontramos:

(...) Cunhambebe tinha a sua frente um grande cesto cheio de carne humana. Comia de uma perna, segurou-a diante da boca e perguntou-me se também queria comer. Respondi: 'Um animal irracional não come um outro parceiro, e um homem deve devorar um outro homem?' Mordeu-a então e disse: '(...) Sou um jaguar. Está gostoso'. Retirei-me dele, à vista disto (STADEN, 1974, p. 132 apud STEIGLEDER, 2010, p. 79).

A obra foi um sucesso editorial com várias edições e traduções para o inglês, francês, português e latim. A autoria das imagens em xilogravura presentes na obra é desconhecida, mas possivelmente elaboradas sob sua própria supervisão, chamando a atenção, sobretudo, para os rituais antropofágicos, como demonstram as Figuras 3 e 4: 
Figura 3: Assando os pedaços do corpo do prisioneiro.

$$
\text { VIAGEM AO BRASIL }
$$

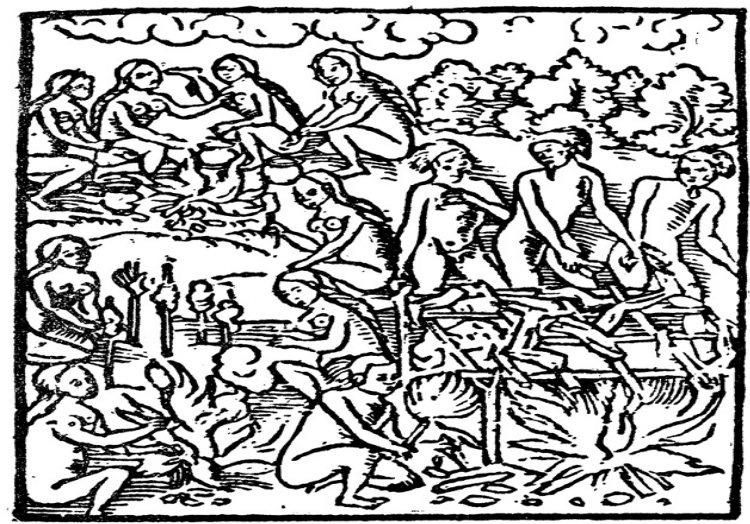

De manhã antei de clàrear o dia, vão thursar e cantar ao redor do bestão com que o devem matar Tiram cotz̃o o prisioneiro da

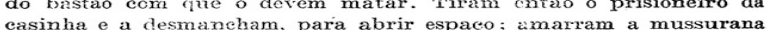
casinha e a desmancham, para abrix espaco; imarram a mussurana ao pescoso e em redor do corpo do paciente, esticando-a para os
dois lados. Irica elle entáo no meio, amarrado, e muitos delles a segurarem a corda pelas duas pontas. Deixam no assim fiear por algum tempo; dão-lhe pedrinhas para elle arrcmessar sobre as mutheres que andam em roda ameaçando de devoral-o. Estão ellas então pintadas e promptas para, quando o prisioneiro estiver reduzido a postas, eomerem os quatro primeiros pedacos ao redor das ca-

\section{3}

Fonte: STADEN (1930, p. 163).

Figura 4: Antropofagia entre Tupinambás no Brasil.

$$
\text { HAIS STADEN }
$$

\footnotetext{
de ficar em reponso, deitado na sua recle e the dão um pequeno arco com nma flecha para passar o tempo atirando em um alvo de cêra. Isto é feito para que os braços nãa fiquem incertos, do susto de ter matado.
}

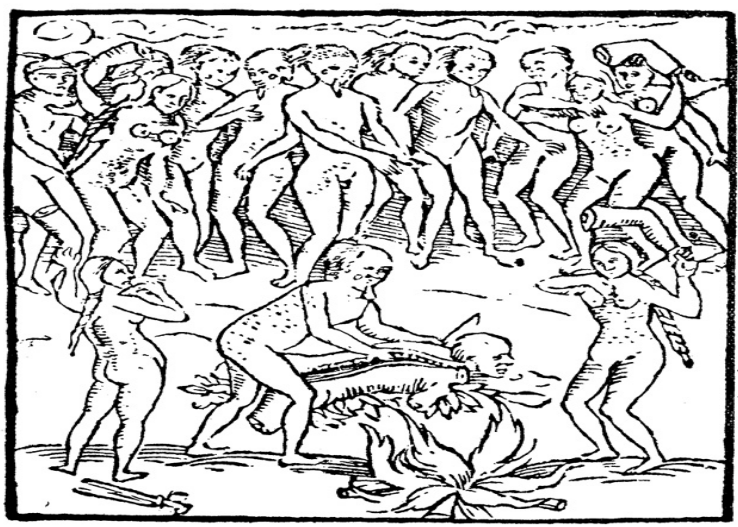

Tuklo isto vi eu e presenciei.

Elles não sabem contar senão até cinco. Si querem contar mais, mostram os cledos da mão e do pé. Em querendo falar de um numero grande, apontam quatro ou cinco pessoas, indicando quantos dedos da mão e do pé ellas têm

168

Fonte: STADEN (1930, p. 168). 
Nessas imagens, nota-se o protagonismo feminino na preparação do cadáver para consumo. Para o historiador Ronald Raminelli, a postura misógina da Idade Média - a mesma que, sob a acusação de bruxaria, já havia condenado milhares de mulheres às fogueiras da Inquisição - serviu de referência às produções iconográficas que, nos séculos XVI e XVII, enfatizaram o protagonismo das indígenas nos rituais canibais. Se a crença medieval na estreita relação das mulheres com o universo das potestades demoníacas era fato, destacar a atuação das mulheres nos festins canibais era o caminho mais rápido de convencer o quanto a América poderia ser bárbara. Diante da dificuldade em ilustrar o desconhecido, tanto Staden como o seu gravurista não partiram do nada, mas de um imaginário de horror povoado por mulheres bruxas e malvadas. No que se refere à repetitiva aparição das mulheres em gravuras de festins canibais - não só com Staden, mas em muitos outros relatos de viagem -, Raminelli destaca:

(...) as imagens foram produzidas a partir dos relatos dos viajantes, que somadas ao imaginário europeu, reforçaram a ideia de que as terras recém-descobertas estavam recheadas de seres fantásticos. As imagens constroem a representação de um ambiente de horror, e deste modo, as mulheres canibais que já ocupavam um espaço no imaginário cristão europeu, serviram para recriar uma ambientação infernal, (...) uma atmosfera fantástica e atemorizadora bem ao gosto da época (RAMINELLI, 1996, p. 105).

Sob esta ótica, as narrativas acerca do consumo de carne humana na América causaram tamanha comoção na Europa que esteve no centro do histórico debate de Valladolid (1550 - 1551), protagonizado pelo frade dominicano Bartolomé de Las Casas - em “defesa” dos indígenas - e pelo teólogo Ginés Sepúlveda - apoiador ferrenho da colonização. Sepúlveda foi irredutível em seu discurso ao tratar os indígenas como a amostra mais consumada da barbárie. Não que Las Casas descartasse a ideia de barbárie indígena, pois, de certa forma, o mito do "buen salvaje” - argumento por ele utilizado na “defesa” dos indígenas - não está muito longe dessa sentença. Ele, contudo, acreditava que essa condição poderia ser facilmente revertida por meio da evangelização. Sepúlveda, por sua vez, defendia a guerra como o único caminho possível.

\section{A invenção da América por meio dos relatos de viagem}

Na definição da palavra “invenção”, o Dicionário Aurélio (FERREIRA, 2010, p. 1180) a relaciona, entre outras, com a palavra “ficção”, a respeito da qual a historiadora Sandra Pesavento esclarece:

Por ficção, Natalie Davis não entende nem a falsidade nem a fantasia, versões vulgares de compreensão do conceito, nem ainda uma possibilidade de invenção absoluta dos dados do real. Prefere o sentido antigo do termo, 
recolhido do século XVI: aquilo que é trabalhado, construído ou criado a partir do que existe (PESAVENTO, 2004, p. 53-54).

É muito apropriado partirmos da invenção da América como um trabalho de ficção, por se tratar de um processo narrativo que demanda imaginação, construção e seleção. Isso nos leva a pensar que tudo o que a América passou a representar aos olhos do Ocidente não estava pronto em 1492, mas foi resultado de um longo processo de ficção/invenção. Esse tipo de constatação se torna ainda mais evidente ao levar em consideração a observação de Machado e Pageux (1988, p. 35), quando destacam que "o escritor-viajante, ao tentar fazer obra literária, vai efabular. E o importante, do ponto de vista do estudo literário, é observar segundo que lógica se vai construir esta espécie de 'mentira', segundo que fantasia criadora se vão desenvolver as confidências do viajante”. Entenda-se aqui a “mentira” não no sentido negativo de enganar, mas de imaginação e fantasia, o que nos livra da ingrata tarefa de identificar o que é verdade ou não em um determinado relato de viagem, mas quais elementos da imaginação e da fantasia os viajantes se utilizaram para ficcionalizar suas experiências pela América, o que aqui entenderemos como parte de um processo de invenção/ criação. Como evidenciado por Cunha (2012, p. 161), “é evidente que, em literatura, os textos não são verdadeiros nem falsos, na sua dimensão verbal, na medida em que funcionam dentro de um sistema, o literário, que detém as suas próprias regras, avessas a critérios de verdade ou de falsidade”. A observação é igualmente pertinente para se pensar a literatura de viagem da qual estamos tratando, cujos autores tinham referências ideológicas e culturais totalmente distintas das existentes na América.

Cristóvão (1999, p. 25) pontua algumas situações que, nesse trabalho, reforçam a ideia de invenção da América por meio da literatura de viagem. $\mathrm{O}$ autor cita o quanto os editores das narrativas de viagem "deixaram de reproduzir as narrativas originais, e decidiram apresentá-las 'trabalhadas', em função do gosto dos leitores”. O retoque ou alteração das narrativas originais - que por si só já tem uma enorme carga de imaginação - por parte das editoras, para atender ao gosto do seu público, reforça ainda mais a ideia de invenção do Novo pelo Velho Mundo. A própria inclusão de ilustrações em relatos que originalmente não as tinham é um exemplo disso, como é o caso de Mundus Novus. A publicação dos relatos de viagem moldou enormemente o olhar de superioridade do europeu sobre a América ao estabelecer uma clara oposição entre Velho Mundo e Novo Mundo, originando um emaranhado de outras oposições: civilização/barbárie; ordem/desordem; evoluído/primitivo; homem/animal, entre outras.

O historiador Edmund O’Gorman, em La invención de América, trabalha com a hipótese de que o termo “descobrimento” não explica satisfatoriamente a "aparição” da América e sua relação com a cultura dita ocidental. Para o autor, o principal problema desse termo é supor que a forma 
como o europeu passou a enxergar esse continente, a partir de então, data de modo pronto, acabado e imediato já em 1492. O’Gormann (2006, p. 13) é da posição de que a América não é produto de um descobrimento, mas de um processo de invenção levado a cabo pelo pensamento ocidental e que “tiene un largo proceso de gestación”. O autor é categórico ao dizer que:

(...) el mal que está en la raíz de todo el proceso histórico de la idea del descubrimiento de América consiste en que se ha supuesto que ese trozo de materia cósmica que ahora conocemos como el continente americano ha sido eso desde siempre, cuando en realidad no lo ha sido sino a partir del momento en que se le concedió esa significación, y dejará de serlo el día en que, por algún cambio en la actual concepción del mundo, ya no se le conceda (O’GORMAN, 2006, p. 61).

O autor reforça que "invenção" é um conceito fundamental para se entender a história da América - acrescentaríamos história de sujeição aos interesses da Europa. Obviamente, não estamos defendendo a suficiência do argumento de O’Gorman. Caso isso ocorresse, incorreríamos no erro de enxergar esse continente como produto de um processo pautado apenas pelo Ocidente, ignorando a enorme capacidade dos povos habitantes da América em também inventar, construir e imaginar a si mesmos, oferecendo outras formas de serem vistos pelo resto do mundo. Contudo, o posicionamento de O’Gorman é bastante pertinente e capaz de nos esclarecer questões importantes acerca dos relatos de viagem dos viajantes europeus do século XVI que pretendiam anunciar a América ao resto do mundo. Nesse processo, destacamos a literatura de viagem que surgiu a respeito do Novo Mundo. Chamamos a atenção para o trabalho de imaginação, construção e seleção que tiveram escritores e ilustradores em ressaltar esse ou aquele aspecto, em grande parte, a partir daquilo que a Europa definiu como barbárie. Podemos entender a invenção da América como um largo esforço aplicado pela cultura ocidental em anunciar a diferença cultural do Novo Mundo como o espectro da barbárie. Na abertura de sua obra, Staden é firme ao dizer:

Descrição verdadeira de um país de selvagens nus, ferozes e canibais, situado no Novo Mundo América, desconhecido na terra de Hessen, antes e depois do nascimento de Cristo, até que, há dois anos, Hans Staden de Homberg, em Hessen, por sua própria experiência, o conheceu e agora a dá à luz pela segunda vez, diligentemente aumentada e melhorada (STADEN, 1930, p. 13).

Os viajantes sabiam que seus relatos poderiam ser alvos de acusações, afinal eles estavam descrevendo situações e modos de vida totalmente desconhecidos, difíceis de serem acreditados. Chama a atenção o fato de Staden apresentar seu relato como uma “descrição verdadeira”, assegurada pela "sua própria experiência” em ter conhecido a América, convencendo o leitor que se tratava de um lugar habitado por "selvagens nus, ferozes e canibais”. Ou, 
como bem observa Azevedo (1999, p. 320), Staden não deixou de afirmar que o conteúdo do seu livro era resultado de tudo o que ele tinha visto e presenciado, "talvez por uma necessidade de dar credibilidade àquilo que descrevia”. Os relatos de Staden, que para o historiador Jean França (2012, p. 103), tiveram "um peso enorme na construção da imagem dos habitantes do Novo Mundo”, conferem à experiência pessoal um estatuto de verdade, atestando sobre a barbárie indígena que estava sendo representada por meio de textos e imagens.

Postura semelhante é adotada por Thevet. Acerca das descrições presentes em seu relato, defende: “(...) e tudo representado visualmente por meio de ilustrações que tentei fazer com a máxima fidelidade possível” (THEVET, 1978, p. 14 apud STEIGLEDER, p. 45). Ainda mais interessantes são as passagens em que ele critica algumas imagens produzidas por artistas que, por nunca terem visto um índio pessoalmente, o ilustravam com o corpo coberto de pelos: "muita gente compartilha da absurda ideia de que estes a quem chamamos de selvagens teriam, pelo fato de viverem pelos campos e florestas quase que como animais, os corpos recobertos de pelos, assim como os ursos, cervos ou leões. (...) Nada mais falso (...)” (THEVET apud STEIGLEDER, 2010, p. 62). Para Thevet, esse equívoco era proveniente do fato de esses artistas nunca terem visto pessoalmente um índio, reproduzindo a opinião geral de que essa era a real aparência física dos que habitavam a América. Em seu relato ele afirma:

(...) esta certeza não advém da observação pessoal, já que tais pessoas jamais depararam com um selvagem, mas meramente do fato de ser esta opinião geral. Quanto a mim, que tive a oportunidade de vê-lo pessoalmente, posso afirmar seguramente que o aspecto dos selvagens é exatamente o oposto (THEVET, 1978, p. 102-107 apud STEIGLEDER, 2010, p. 62).

Portanto, Thevet justifica a veracidade do seu relato por ser resultado de uma experiência pessoal. Esse viajante argumenta:

(...) Dou aqui a localização e a situação dos lugares, definindo seu clima, sua zona e seu paralelo, informando se se trata de mar, de ilha ou de terra firme, além de descrever a temperatura do ar, os costumes e modos de vida dos habitantes, o aspecto e as características dos animais aquáticos e terrestres, das árvores, dos arbustos e de seus respectivos frutos, dos minerais e das pedras preciosas, e tudo representado visualmente por meio de ilustrações que tentei fazer com a máxima fidelidade possível (THEVET, 1978, p. 13-14 apud FRANÇA, 2012, p. 107-108).

A “máxima fidelidade possível” indicava a intenção de apresentar aquela narrativa de viagem como imitação fiel da realidade, como se fosse quase possível substituir a experiência particular do leitor em conhecer a América. Para a pesquisadora Paula Cristina Lopes (s.d., p. 4), falar de 
literatura "é falar inevitavelmente de imitação. De facto, descrever a literatura como arte é considerá-la uma forma de imitação, um meio de reprodução e recriação através da palavra”. Nesse sentido, é compreensível a literatura de viagem ter contribuído para a ideia de barbárie indígena, visto que essa condição foi atestada pela experiência pessoal do viajante. Como colocado por França (2012, p. 284), “as narrativas de viagens ocuparam um papel central na construção intelectual (...) daqueles novos mundos que a expansão marítima integrava ao Velho Mundo”. Portanto, chamamos a atenção para o poder de convencimento desses relatos de viagem que, apresentados como cópia fiel do real, foram tomados como estatuto de verdade.

França (2012, p. 285) explica que os discursos apregoados nos relatos de viagem tiveram "larga aceitação entre o público e que desfrutava, entre esse mesmo público, do estatuto de um discurso verdadeiro, ainda que passível de dúvidas, críticas e contestações”. Klinger (2006, p. 174), por sua vez, explica que, para o crítico literário Roland Barthes, o estudo da designação "efeito de realidade" serve para mostrar como "o texto nos leva a aceitar como 'real' seu produto ficcional”. O efeito de realidade pode, então, ser entendido como a busca por uma "garantia de autenticidade e presunção de acesso possível à experiência”. Já para o filósofo Jacques Rancière (2010, p. 79), “o efeito de realidade é um efeito de igualdade”. Por fim, para Todorov (1978, p. 15-16 apud LOPES, s.d., p. 5) “... a literatura é imitação pela linguagem, tal como a pintura é imitação pela imagem”. Essas considerações nos interessam sobremaneira, pois estamos diante de relatos de viagens com estatuto de verdade e que por séculos foram as únicas referências acerca da América, atuando como uma sentença sobre a percepção do que, supostamente, seria o Novo Mundo. Como afirmam Machado e Pageaux (1988, p. 45-46), "ao leitor passivo, que não se desloca, o viajante vai comunicar informações que poderão tornar-se preciosas e definitivas, princípio de reflexão e de juízo”.

França (2012, p. 85-86), em uma análise sobre a construção do Brasil através da literatura de viagem dos séculos XVI ao XVIII, entende os relatos de viagem como "um dos vetores mais importantes, quiçá o mais importante, no lento processo de construção do Novo pelo Velho Mundo” e, o mais interessante, "encontraram um público receptivo, benevolente e crédulo, ansioso por notícias dos novos mundos”. Referindo-se especificamente ao caso brasileiro, o autor é seguro ao dizer que "não seria precipitado asseverar que uma parte considerável do que os europeus conheceram acerca do Brasil proveio, em larga medida, de umas duas dezenas de relatos mais conhecidos” (FRANÇA, 2012, p. 191). Essas considerações sustentam nosso argumento sobre a importância das narrativas de viagem no longo processo de invenção da América.

Alguns autores, inclusive, identificam nesses primeiros relatos de viagem a justificativa sobre a qual se autorizou a violenta dominação da 
Europa sobre a América. É o caso, por exemplo, de Barriendos. O autor chama a atenção para o impacto dos "regímenes visuales racializantes producidos tras la ‘invención’ del 'Nuevo Mundo'” por terem constituido “la matriz heterárquica de poder a partir de la cual operan en la actualidad la colonialidad del ver y el racismo epistemológico” (BARRIENDOS, 2011, p. $15)^{1}$. O que mais chama a atenção, pelo menos para a reflexão proposta nesse trabalho, é que, em sua argumentação, o autor destaca o quanto o canibalismo também foi veiculado "por la literatura de viajes de los conquistadores" e “por los relatos de los cronistas de Indias”, podendo ser colocado como um dos "elementos constitutivos del sistema-mundo moderno/colonial" (BARRIENDOS, 2011, p. 17-18)². Citando viajantes como Hans Staden, o autor explica que esses relatos tiveram um grande poder ontológico ao propagar uma América canibal, o que reforçava a defesa pela colonização. Não é por acaso, então, que, para Cristóvão:

As barreiras morais foram sendo vencidas por complicadas argumentações contra o estado de ignorância da fé cristã por parte de muitos povos, contra a ilegitimidade de se ser "infiel”, e a favor da urgência da evangelização e do Baptismo, contra a maldade dos cultos idolátricos e das práticas contra a lei natural, como as da antropofagia e da poligamia, preconizando todas elas iniciativas cristãs para se pôr termo a esse estado de coisas (CRISTÓVÃO, 1999, p. 43).

Logo, é possível inferir que a ideia de América não se definiu em 1492, como o termo “descoberta” poderia indicar, mas foi resultado de um longo processo de invenção/criação, forjado no seio de sociedades que interpretaram a diferença como motivo e justificativa para a colonização. Tratamos, portanto, de narrativas de viagem que inventaram a ideia de Novo Mundo, descrevendo uma América bárbara, habitada por índios canibais e repleta de elementos estranhos à “civilização”.

\section{Considerações finais}

Na Europa do século XVI, ainda pouco se sabia sobre a América. Aos viajantes que retornavam, restava a incumbência de descrever esse lugar, o que deu origem a diversas narrativas que hoje compõem o gênero literatura de viagem. Os relatos Mundus Novus, Duas viagens ao Brasil e As singularidades da França Antártica podem ser analisados como parte do processo de invenção da América desde a Europa, uma vez que davam a conhecer práticas que não correspondiam com as referências políticas, sociais e culturais que, para o Ocidente, seriam indicativas de uma sociedade civilizada. Essas produções descreveram a realidade cultural da América como sinônimo de barbárie, forjando visões distorcidas que passaram a ser largamente utilizadas como justificativas para a colonização desse continente e seus habitantes. Nessas narrativas, o destaque pesou, sobretudo, sobre a
${ }^{1} \mathrm{O}$ autor chama a atenção para o impacto dos "regimes visuais racializantes produzidos após a 'invenção' do 'Novo Mundo'” por terem constituído "a matriz heterárquica de poder a partir da qual operam atualmente a colonialidade do ver e o racismo epistemológico" (BARRIENDOS, 2011, p. 15, tradução nossa).

${ }^{2} \mathrm{O}$ que mais chama a atenção, pelo menos para a reflexão proposta nesse trabalho, é que, em sua argumentação, o autor destaca o quanto o canibalismo também foi veiculado "pela literatura de viagens dos conquistadores" e "pelos relatos dos cronistas das Índias”, podendo ser colocado como um dos "elementos constitutivos do sistema-mundo moderno/colonial" (BARRIENDOS, 2011, p. 17-18, tradução nossa). 
nudez e o consumo de carne humana, o que intensificou o choque com a mentalidade ocidental. Devido à grande recepção que tiveram na Europa, essas obras podem ser pensadas como agentes importantes no processo de invenção da América desde o Ocidente.

\section{Referências}

ALMEIDA, Maria Cândida Ferreira de. Tornar-se outro: o topos canibal na literatura brasileira. São Paulo: Annablume, 2002.

APOCALIPSE. In: BÍBLIA Sagrada. Português - Inglês. Antigo e novo testamento. São Paulo: Editora Vida, 2003.

AZEVEDO, Ana Maria de. O índio brasileiro (o olhar quinhentista e seiscentista). In: CRISTOVÃO, Fernando (Coord.) Condicionantes culturais da literatura de viagens. Estudos e bibliografias. Lisboa: Edições Cosmos, 1999. p. 304-335.

BARRIENDOS, Joaquín. La colonialidad del ver. Hacia un nuevo diálogo visual interepistémico. Nómadas, Universidad Central, Colombia Out. 2011. Disponível em: <https://dialnet.unirioja.es/descarga/ articulo/3818537.pdf>. Acesso em: 17 jul. 2018.

CHICANGANA-BAYONA, Yobenj Aucardo. Visões de terras, canibais e gentios prodigiosos. ArtCultura, Uberlândia, v. 12, n. 21, p. 35-53, jul.dez. 2010. Disponível em: <http://www.artcultura.inhis.ufu.br/PDF21/y_ bayona.pdf>. Acesso em: 14 jul. 2018.

CRISTÓVÃO, Fernando. Para uma teoria da Literatura de Viagens. In: CRISTOVÃO, Fernando (Coord.) Condicionantes culturais da literatura de viagens. Estudos e bibliografias. Lisboa: Edições Cosmos, 1999. p. 15-73.

CUNHA, Paula Cristina Ribeiro da Rocha. Apontamentos teóricos sobre Literatura de Viagens. [S.l.], Caracol, n. 3, p. 152-173, jun. 2012. Disponível em: $\quad$ <https://www.revistas.usp.br/caracol/article/view/57686/60741>. Acesso em: 13 jun. 2018.

FERREIRA, Aurélio Buarque de Holanda. Dicionário Aurélio da língua portuguesa. 5. ed. Curitiba: Positivo, 2010. p. 1180.

FRANÇA, Jean Marcel Carvalho. A construção do Brasil na literatura de viagem dos séculos XVI, XVII e XVIII: antologia de textos (15911808). São Paulo: UNESP, 2012.

KLINGER, Diana Irene. Escritas de si, escritas do outro: autoficção e etnografia na narrativa latino-americana contemporânea. 2006. Tese (Doutorado em Letras) - Instituto de Letras, Universidade do Rio de Janeiro, Rio de Janeiro. Disponível em: <http://www.dominiopublico.gov. 
br/pesquisa/DetalheObraForm.do?select_action=\&co_obra=198038>. Acesso em: 25 jul. 2018.

LOPES, Paula Cristina. Literatura e linguagem literária. Disponível em: <http://bocc.ubi.pt/pag/bocc-lopes-literatura.pdf>. Acesso em: 12 jul. 2018.

MACHADO, Álvaro Manuel; PAGEAUX, Daniel-Henri. As experiências da viagem: da literatura comparada à teoria da literatura. Lisboa: Edições 70, 1988. p. 33-51.

O’GORMAN, Edmundo. La invención de América: investigación acerca de la estructura histórica del Nuevo Mundo y del sentido de su devenir. 4. ed. México: FCE, 2006.

PESAVENTO, Sandra Jatahy. História \& história cultural. Belo Horizonte: Editora Autêntica, 2004.

RAMINELLI, Ronald. Imagens da colonização: a representação do índio de Caminha a Vieira. São Paulo/Rio de Janeiro: Edusp/Fapesp/Jorge Zahar, 1996.

RANCIÈRE, Jacques. O efeito de realidade e a política da ficção. CEBRAP, São Paulo, n. 86, p. 75-80, Mar. 2010. Disponível em: <http://www.scielo.br/scielo.php?script=sci_arttext\&pid=S010133002010000100004\&lng=en\&nrm=iso>. Acesso em: 15 jun. 2018.

STADEN, Hans. Viagem ao Brasil. Versão do texto de Marpurgo, de 1557. Rio de Janeiro: Officina Industrial Graphica, 1930. Biblioteca Nacional de Portugal. Disponível em: <http://purl.pt/151/1/index.html\#/1>. Acesso em: 03 dez. 2018.

STEIGLEDER, Carlos Geovane. Staden, Thevet e Léry: olhares europeus sobre o índio e sua religiosidade. São Luís: Edfuma, 2010.

THEVET, André. Les singularitez de la France antarctique. Paris: Maisonneuve \& cie Libraries Editeurs, 1878. Disponível em: <https:// gallica.bnf.fr/ark:/12148/bpt6k411316v/f261.item.zoom>. Acesso em: 03 dez. 2018.

VESPÚCIO, Américo. Novo Mundo. As cartas que batizaram a América. São Paulo: Editora Planeta, 2003.

Enviado em agosto/2018.

Aceito dezembro/2018. 